\title{
2 次形式評価関数の荷重行列と最適有限整定制御系の設計
}

\author{
学生員 松島優一 (広島工業大学) \\ 学生員 若宮真一郎 (広島工業大学) \\ 正 員 村田弘志 （広島工業大学）
}

Weighting Matrix of Quadratic Performance Index and Design Method of Optimal Deadbeat Control System.

\author{
Yuichi Matsushima, Student Member \\ Shinichiro Wakamiya, Student Member \\ Hiroshi Murata, Member \\ (Hiroshima Institute of Technology)
}

\begin{abstract}
In this paper, are discussed a determination method of weighting matrix of quadratic performance index and a design method of optimal deadbeat control system. First, the relationship between weighting matrix of quadratic performance index and extra pole of over-parameterized pulse transfer function model is indicated. Next, a design method of optimal deadbeat control system is explained. Lastly, to demonstrate the effectiveness of the proposed method, some numerical examples are also presented.
\end{abstract}

キーワード：2次形式評価関数，荷重行列，最適有限整定制御，デッドビート制御，ディジタル制御

\section{1. まえがき}

忘答波形の改善や操作量制限への対応肪可能な最適有限 整定制御系の設計については，主ループ内の緩和フィルタ と状態局部フィードバックを用いる西村ら ${ }^{1,2)}$ の方法や, 制 御対象に前置補償器を加え状態つィードバックにより局部 補償を行う瓜倉ら ${ }^{3,4)}$ の方法が上く知られている。いずれも 制御対象の次数を $n$ とするとき最適制御段数 $N$ を $N=n+k(k>0)$ として自由度を増し, 操作量と偏差に関寸る2 次形式評価関数を最小化する状態フィードバック制御系の 設計法であり，設計にあたっては制御段数 $N$ と評価関数に お子る操作量と偏差に対する荷重行列 $Q, R$ を任意に選九 でフィードバックゲインと補償器のパラメータを決定し, その後閉ル一プ采の入・出力特性を求めて制御仕様老满た すよう試行を重㸚ている。

筆者らも同様な制御構成と評価関数を用いた最適有限整 定制御系の設計について, 制御対象のステップ応答を用い た簡单な行列演算から最適有限整定操作量 $\boldsymbol{u}_{k}$ 老求め, この 操作量に対方る制御対象の応答を閉ループ系の規範応答と する最適有限整定サ一ボ系の設計法を提案している。この 設計手法であれば，規範モデル応答が制御仕様を満たして いるかを最適有限整定操作量 $u_{k}$ が求まった段階で事前に確 認してから制御系を設計すればよく，これまでの手法 の上うに制御装置設計後に閉ループ系の応答を求めて試
行を繰返す必要がなく、設計手法が簡単である。

ところで，いずれの場合においても2 次形式評価関数の 荷重行列 $Q, R$ の值をいかに取るかは試行を行う以外ない。 しかし，筆者らの手法により $\boldsymbol{u}_{k}$ から得られるオーバパラ メータパルス伝達関数 (モデル) を $\bar{G}(z)$ と定めれば， $\bar{G}(z)$ の分母子に含まれる追加多項式 $\lambda(z)=0$ の根 $\psi_{i}(i=1 \sim k)$ （以 後, ”追加極” 亡称与る) $と Q=q I, R=r I$ ( $I$ : 单位行列) 関係を導出したところ, 追加極を $z$ 平面の単位円上に配置 するとき，制御対象のダイン $K$ に対して $q K^{2}=r な る$ 条件式 を满足すればよいことが証明できる。この条件を満たすよ $う に q, r$ を選んで追加極を単位月の近傍に配置した規範モ デルを作れば，良好な制御応答が得られ制御对象のパラ メータ変動に対しても比較的頑健なサーボ系の設部ができ ることが確認できた。

最適有限整定サ一ボ系の設計において, 最適制御段数 $N$ と荷重行列 $Q, R$ の選抧をいかに上るか怄大きな課題である が，本論文の結果は設㖕に拈ける一つの目安孝与えるもの と思われる。また本手法は，これまで提案されている最適 有限整定サーボ系における種々の制御構成に対しても適用 できる。文献1）で提案されている制御構成による最適有 限整定サ一ボ系の本手法による設計例を定位性と無定位性 の系について示し，ステップ状目標值に対する応答をディ ジタルシミュレーションに上って求め検討を加えた。 


\section{2. 最適有限整定操作量とオーパパラメータモデル}

入力を $u(t)$, 出力を $y(t)$, 制御対象の伝達関数を $G(s)$ 之 する単一入出力系を考え， $G(s)$ の次数を $n$, ゲインを $K$, ステップ応答を $h(t)$, サンプル周期を $\theta$ とし, 例えば出力 $y(t)$ について離散值を $y=y(i \theta)$ なる表現を用いる。

一方, 系の状熊方程式と出力方程式が可制御正淮形とし て $x_{i+1}=\Phi x_{i}+\Gamma u_{i}, y_{i}=\Psi x_{i}$ で表されているとし, 対応する パルス伝達関数を次のように定める。

$$
\begin{aligned}
& G(z)=\frac{b(z)}{1+a(z)}=\sum_{i=1}^{\infty} g_{i} z^{-i} \\
& a(z)=a_{1} z^{-1}+a_{2} z^{-2}+\cdots+a_{n} z^{-n} \\
& b(z)=b_{1} z^{-1}+b_{2} z^{-2}+\cdots+b_{n} z^{-n} \\
& \left(g_{i}=\Psi \Phi^{i-1} \Gamma=h_{i}-h_{i-1}\right)
\end{aligned}
$$

このとき，パルス伝達関数のパラメータ $a_{i}, b_{i}(i=1 \sim n)$ とマ ルコフパラメータ $g_{i}(i=1,2, \cdots)$ の間に流次式方成立してい る。

$$
g_{i}= \begin{cases}b_{i}-\sum_{j=1}^{i-1} a_{j} g_{i-\cdots j} & \left(i=1 \sim n, g_{0}=0\right) \\ -\sum_{j=1}^{n} a_{j} g_{i-j} & (i \geqq n+1)\end{cases}
$$

なお、1形サーボ系の構成省想定し制御対象が $z=1$ に零 点在持たない条件として

$$
\operatorname{rank}\left[\begin{array}{cc}
\Phi-I & \Gamma \\
\Psi & 0
\end{array}\right]=n+1
$$

\section{を満たしているものとする。}

ここで, 制御段数を $N$ とし， $N=n+k(k \geqq 0)$ なる任意な值 に対して，入力心゙クトルを $\boldsymbol{u}_{k}$, 伝達マトリクスを $G$ とす れば，(N+1)段にわたる出力答心゙クトルyは

$$
\boldsymbol{y}=\left[y_{1}, y_{2}, \cdots, y_{N+1}\right]^{T}=G \boldsymbol{u}_{k}
$$

上表される。ただし

$$
\begin{aligned}
\boldsymbol{u}_{k} & =\left[u_{0}, u_{1}, \cdots, u_{N}\right]^{T} \\
G & =\left[\begin{array}{cccc}
g_{1} & 0 & \cdots & 0 \\
g_{2} & g_{1} & \ddots & \vdots \\
\vdots & \vdots & \ddots & 0 \\
g_{N+1} & g_{N} & \cdots & g_{1}
\end{array}\right]
\end{aligned}
$$

である。この出力忘答 $v$ と目標值ベクトル $i_{r}=[1, \cdots, 1]^{T}((N+$ 1) ×1)との偏差ベクトルを $e$ とすれば

$$
e=i_{r}-G \boldsymbol{u}_{k}=\left[e_{1}, e_{2}, \cdots, e_{N+1}\right]^{T}
$$

上表されるので, 正定対称な $(N+1) \times(N+1)$ 荷重行列を $Q$, $R$ として，次式の評洒関数 $P$ を定める。

$$
P=\frac{1}{2}\left(\boldsymbol{e}^{T} Q e+\boldsymbol{u}_{k}^{T} R \boldsymbol{u}_{k}\right)
$$

ここで，ステップ状目標值に対し，制御段数を $N=n+k$ $(k \geqq 0)$ と $\boldsymbol{u}_{j}(j=0 \sim N-1)$ なる操作量で制御刘象の出力灾答 $y_{i}$ 老 $N$ 段以降目標值に有限整定させたとすれば， $y_{i}=1.0$ $(i \geqq N), u_{N}=u_{N+\beta}(\beta \geqq 1)$ なる一定值をとることから，(4)式 $D y_{i}(i=N \sim N+n)$ につてこれらの条件を代入して整理すれ ば次式老得る。

$$
\begin{aligned}
\boldsymbol{i}=J_{k} u_{k} & =J_{k}\left[u_{0}, u_{1}, \cdots, u_{N}\right]^{T} \\
& =[1,1, \cdots, 1]^{T}
\end{aligned}
$$

ただし

$$
J_{k}=\left[\begin{array}{cccccccc}
g_{N} & g_{N-1} & \cdots & g_{n+1} & g_{n} & \cdots & g_{1} & 0 \\
g_{N+1} & g_{N} & \cdots & g_{n+2} & g_{n+1} & \cdots & g_{2} & h_{1} \\
\vdots & \vdots & & \vdots & \vdots & & \vdots & \vdots \\
g_{N+n} & g_{N+n-1} & \cdots & g_{2 n+1} & g_{2 n} & \cdots & g_{n+1} & h_{n}
\end{array}\right]
$$

である。

ここで, $k=0$ の場合 $J_{k}\left(=J_{0}\right)$ は $(n+1) \times(n+1)$ 行列となり $\left|J_{0}\right| \neq 0$ が成立主るので $(9)$ 式より最短時間有限整定操作量 $u_{0}$ は次式から得られる。

$$
\boldsymbol{u}_{0}=J_{0}^{-1} \boldsymbol{i}=\left[u_{0}, u_{1}, \cdots, u_{n}\right]^{T}
$$

(11) 式で得られる最短時閒有限整定操作量 $u_{i}(i=0 \sim n)$ と (1) 式の $G(z)$ の゚ラメータ $a_{i}, b_{i}(i=1 \sim n)$ の間に泣次式が成 立している。

$$
\left.\begin{array}{l}
a_{i}=\left(u_{i}-u_{i-1}\right) / u_{0} \\
b_{i}=\left(y_{i}-y_{i-1}\right) / u_{0}
\end{array} \quad\left(u_{0}=1 / \sum_{j=1}^{n} b_{j}\right) \quad\right\}
$$

ただし， $y_{i}$ は $u_{i}$ に対する系の有限整定灾答である。

また， $k \geqq 1$ の場合には $J_{k}$ 方 $(10)$ 式のように $(n+1) \times$ $(N+1)$ 行列で, $\operatorname{rank} J_{k}=n+1$ となり $\boldsymbol{u}_{k}$ は一意に定まらない。 そこで，（9）式から $\boldsymbol{i}-J_{k} \boldsymbol{u}_{k}=\mathbf{0}$ を拘束条件として(8)式の評 価関数 $P$ を最小化する操作量をラグランジェの未定係数法 を用いて求め礼ば，最適有限整定操作量 $\boldsymbol{u}_{k}$ が次式から得ら れる。5,6,7)

$$
\begin{aligned}
\boldsymbol{u}_{k} & =M^{-1}\left[G^{T} Q i_{r}-J_{k}^{T}\left[J_{k} M^{-1} J_{k}^{T}\right]^{-1}\left[J_{k} M^{-1} G^{T} Q i_{r}-i\right]\right] \\
& =\left[\bar{u}_{0}, \bar{u}_{1}, \cdots, \bar{u}_{N}\right]^{T} \\
M & =\left[R+G^{T} Q G\right] \\
i_{r} & =[1,1, \cdots, 1]^{T}
\end{aligned}
$$

同様に，(13) 式で得られる最適有限整定操作量 $\bar{u}_{i}(i=0 \sim$ $N)$ に対主る矛の出力店答を $\bar{y}_{i}$ と古れば，(12)式と同様にし $\tau$ 


$$
\begin{aligned}
& \bar{a}_{i}=\left(\bar{u}_{i}-\bar{u}_{i-1}\right) / \bar{u}_{0} \\
& \bar{b}_{i}=\left(\bar{y}_{i}-\bar{y}_{i-1}\right) / \bar{u}_{0}
\end{aligned} \quad\left(\bar{u}_{0}=1 / \sum_{j=1}^{N} \bar{b}_{j}\right)
$$

が得られ， $\bar{a}(z)=\sum_{i=1}^{N} \bar{a}_{i} z^{-i}, \quad \bar{b}(z)=\sum_{i=1}^{N} \bar{b}_{i} z^{-i}$ として $\bar{G}(z)=\bar{b}(z)$ $/(1+\bar{a}(z))$ なるオ一バパラメータモデルが寒現できる。この $N$ 次のモデルは分母子に $z^{-1} に つ い て ~ k$ 次の追加多項式 $\lambda(z)$ を含み次式のように表される。

$$
\bar{G}(z)=\frac{\bar{b}(z)}{1+\bar{a}(z)}=\frac{b(z) \lambda(z)}{[1+a(z)] \lambda(z)}
$$

ここに, $\lambda(z)$ は

$$
\lambda(z)=1+\sum_{i=1}^{k} \lambda_{i} z^{-i}
$$

であり， $\lambda(z)=0$ の根を”追加極”と称することとする。ま た，(18)式に挍ける $\lambda(z)$ のパラメータ $\lambda_{i} は(17)$ 式の右辺 の分母どうしについて $z^{-1}$ のべき乗の倸数を比較すれば，パ ルス伝達関数のパラメータとの関倸について次式が得られ る。

$$
\lambda_{i}=\bar{a}_{i}-\sum_{j=1}^{n} \lambda_{i-j} a_{j} \quad\left(i=1 \sim k, \lambda_{0}=1, \lambda_{p}=0(p<0)\right)
$$

なお，(13) 式より得られる最適有限整定操作量 $\bar{u}_{i}(i=0 \sim$ N)の柔列を $z$ 領域で表せば $\bar{u}(z)=[1+\bar{a}(z)] \bar{u}_{0} /\left(1-z^{-1}\right)$ とな ることから，この入力系列に対する制御刘象の出力応答の 菜列在 $z$ 領域で表せば

$$
\bar{y}(z)=\bar{u}_{0} \bar{b}(z) /\left(1-z^{-1}\right)
$$

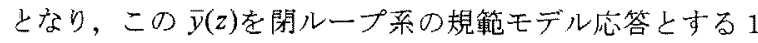
形サーボ系が 5 章で設計される。

3. 最短有限整定操作量と最通有限整定操作量の関 保

本章では，(11)式から得られる最短有限整定揁作量 $\boldsymbol{u}_{0}$ と (13) 式加ら得られる最適有限整定操作量 $\boldsymbol{u}_{k}$ の間に成立する 関係式を誘導する。また， $\boldsymbol{u}_{k}$ より得られる(17)式のオーバ パラメータモデルにおける追加多項式 $\lambda(z)$ のパラメータ $\lambda_{i}$ $(i=1 \sim k)$ との関係を明らかにする。

まず，(10)式で定めた $(n+1) \times(N+1)$ 行列 $J_{k}$ の次元を拡大 し, $(N+1) \times(N+1)$ 行列 $J_{s}$ 老次式Dように定義する。

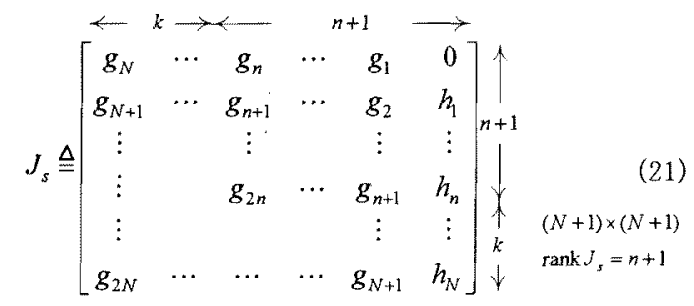

ここで，(11)式から得られる最短時間有限整定操作量 $\boldsymbol{u}_{0}=\left[u_{0}, u_{1}, \cdots, u_{n}\right]^{T}$ に対応した制御対象の出力応答 $y_{i}$ は, $n \theta$ 時点以降は一定值 $y_{i}=1.0(i \geqq n)$ に整定するか力 なる $y_{i}$ について入出力関係老行列表示寸れば

$$
\left.J_{s}\left[\begin{array}{c}
0 \\
\vdots \\
0 \\
0 \\
u_{0} \\
\vdots \\
u_{n}
\end{array}\right]+\begin{array}{c}
k \\
\downarrow
\end{array}\right]=\left[\begin{array}{c}
1 \\
1 \\
\vdots \\
\vdots \\
1
\end{array}\right]
$$

が得られる。同様に，(13)式から得られる最適有限整定操 作量 $\boldsymbol{u}_{k}=\left[\bar{u}_{0}, \bar{u}_{1}, \cdots, \bar{u}_{N}\right]^{T}$ に対応した出力応答 $\bar{y}_{i}$ 注 $N \theta$ 時点 以降は一定值 $\bar{y}_{i}=1.0(i \geqq N)$ に整定するから $i=N \sim 2 N$ につい て整理し行列表示すれば次式を得る。

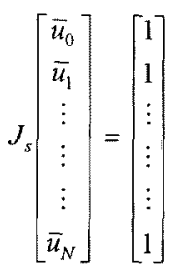

一方，マルコフパラメータ $g_{i}$ とパルス伝達関数のパラ メータ $a_{i}$ の関係は (2) 式加求まり, $g_{i}(i=n+1 \sim 2 n+1)$ につ いて整理すれば

$$
\left[\begin{array}{cccc}
g_{n+1} & \cdots & \cdots & g_{1} \\
g_{n+2} & \cdots & \cdots & g_{2} \\
\vdots & \ddots & & \vdots \\
\vdots & & \ddots & \vdots \\
g_{2 n+1} & \cdots & \cdots & g_{n+1}
\end{array}\right]\left[\begin{array}{c}
1 \\
a_{1} \\
\vdots \\
\vdots \\
a_{n}
\end{array}\right]=\left[\begin{array}{c}
0 \\
0 \\
\vdots \\
\vdots \\
0
\end{array}\right]
$$

となり，(21)式の $J_{s}$ を用いて表示すれば

$$
\left.J_{s}\left[\begin{array}{c}
1 \\
a_{1} \\
\vdots \\
a_{n} \\
\hdashline \\
0 \\
\vdots \\
0
\end{array}\right]+\begin{array}{c}
k \\
k \\
\vdots \\
\vdots \\
\vdots \\
\vdots
\end{array}\right]=0 \quad \rightarrow \quad J_{s}\left[1, a_{1}, \cdots, a_{n}, 0, \cdots, 0\right]^{T}=0
$$

となり, 同様に

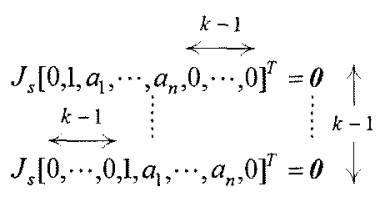

も成立しており， $\left[1, a_{1}, \cdots, a_{n}, 0, \cdots, 0\right]^{T}, \cdots,\left[0, \cdots, 0,1, a_{1}, \cdots, a_{n}, 0\right]^{T}$ 一次独立である。

ここで(23)式の非同次連立方程式考考えるとき，(22) 式 における $\left[0, \cdots, \overrightarrow{0}, u_{0}, \cdots, u_{n}\right]^{T}$ が(23)式の特殊解である。また， rank $J_{s}=n+1$ であるから $J_{s} u_{k}=0$ の解空間の次元は $(N+1)-(n+1)=k$ 上なる。よって任意倸数を $\alpha_{j}(j=1 \sim k)$ とし て(23)式の一般解は次式のように表せ， $\boldsymbol{u}_{k}$ と $\boldsymbol{u}_{0}$ の関係が定 まる。 


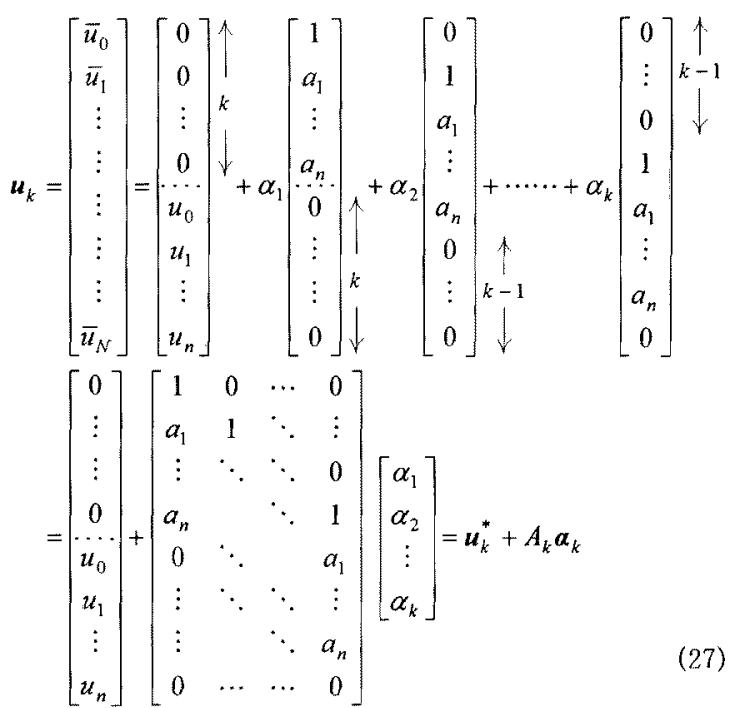

さて，前章の $(16) ，(17)$ 式で求めたように，最適有限整定操 作量 $\bar{u}_{i}(i=0 \sim N)$ がらオーバパラメータモデル $\bar{G}(z)$ が得ら れ, $\bar{G}(z)$ は分母子に $z^{-1}$ について $k$ 次の追加多項式 $\lambda(z)$ を

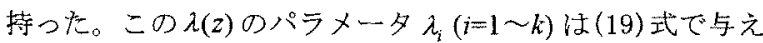
られている。よって，(16)，(19)，(27)式の関係加ら $\lambda_{i}$ と $\alpha$ の関倸を求めれば

$$
\lambda_{i}= \begin{cases}\left(\alpha_{i+1}-\alpha_{i}\right) / \alpha_{1} & (i=1 \sim k-1) \\ \left(u_{0}-\alpha_{i}\right) / \alpha_{1} & (i=k)\end{cases}
$$

が得られる。

以下で簡単化のため, $n=2, N=4(k=2)$ の場合を例にとっ て $\lambda_{i}$ と $\alpha_{i}$ の関係を示す。このとき $u_{0}=\left[u_{0}, u_{1}, u_{2}\right]^{T}, u_{2}=\left[\bar{u}_{0}, \bar{u}_{1}\right.$, $\left.\bar{u}_{2}, \bar{u}_{3}, \bar{u}_{4}\right]^{T}$ となるから(27)式は

$$
\left[\begin{array}{l}
\bar{u}_{0} \\
\bar{u}_{1} \\
\bar{u}_{2} \\
\bar{u}_{3} \\
\bar{u}_{4}
\end{array}\right]=\left[\begin{array}{c}
0 \\
0 \\
u_{0} \\
u_{1} \\
u_{2}
\end{array}\right]+\alpha_{1}\left[\begin{array}{c}
1 \\
a_{1} \\
a_{2} \\
0 \\
0
\end{array}\right]+\alpha_{2}\left[\begin{array}{c}
0 \\
1 \\
a_{1} \\
a_{2} \\
0
\end{array}\right]
$$

と表せ，(16)式より $\bar{a}_{i}=\left(\bar{u}_{i+1}-\bar{u}_{i}\right) / \bar{u}_{0}(i=1 \sim N)$ であるから

$$
\begin{gathered}
\bar{a}_{1}=\frac{\bar{u}_{1}-\bar{u}_{0}}{\bar{u}_{0}}=\frac{\left(a_{1}-1\right) \alpha_{1}+\alpha_{2}}{\alpha_{1}} \\
\bar{a}_{2}=\frac{\bar{u}_{2}-\bar{u}_{1}}{\bar{u}_{0}}=\frac{u_{0}+\left(a_{2}-a_{1}\right) \alpha_{1}+\left(a_{1}-1\right) \alpha_{2}}{\alpha_{1}} \\
: \quad: \quad: \quad
\end{gathered}
$$

となる。また， $\lambda_{i}(i=1,2) は(19)$ 式から $\lambda_{i}=\bar{a}_{i}-\sum_{j=1}^{n} \lambda_{i-j} a_{j}$ とし て得られており

$$
\begin{aligned}
& \lambda_{1}=\bar{a}_{1}-a_{1} \\
& \lambda_{2}=\bar{a}_{2}-\lambda_{1} a_{1}-a_{2}
\end{aligned}
$$

が求まる。（30)式の $\bar{a}_{1} ， \bar{a}_{2} を(31)$ 式に代入し整理すれば

$$
\begin{aligned}
& \lambda_{1}=\left(\alpha_{2}-\alpha_{1}\right) / \alpha_{1} \\
& \lambda_{2}=\left(u_{0}-\alpha_{2}\right) / \alpha_{1}
\end{aligned}
$$

となり，追加多項式 $\lambda(z)$ のパラメータ $\lambda_{i}(i=1 \sim k)$ が任意倸 数 $\alpha_{i}$ から決定できる。この

以上加 5 , 最適有限整定操作量 $\boldsymbol{u}_{k}$ は (8) 式の評価関数 $P$

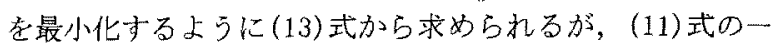
意に定まる最短有限整定操作量 $\boldsymbol{u}_{0}$ と任意係数 $\alpha_{i}$ の関数とし

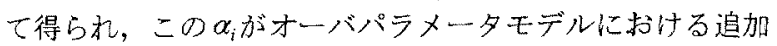
多項式 $\lambda(z)$ のパラメータ $\lambda_{i}$ を(28)式のように定めることが わ加る。よって, $\lambda(z)=0$ の根である”追加極 $\psi_{i}(i=1 \sim k) ”$ をある一定值内に配置する $\alpha_{i}$ が存在し，その上うな $\alpha_{i}$ を与 える評価関数の荷重行列 $Q, R$ が定まる。次章では，追加 極を $z$ 平面の単位円周上に配置する $Q, R$ の関倸式を求め る。

\section{4. 評価関数の荷重行列 $Q, R$ と追加梄}

前章までで，最短有限整定操作量 $\boldsymbol{u}_{0}$ と最適有限整定操作 量 $\boldsymbol{u}_{k}$ の関係およひ，追加多項式 $\lambda(z)$ のパラメータ $\lambda_{i}$ 上任意 係数 $\alpha_{i}$ の関係を求めた。本章では評価関数の荷重行列 $Q, R$ 之追加極の関係を明ら加方るため，(27)式の $\boldsymbol{u}_{k}$ を用いて 偏差 $e$ 求め, この $u_{k}$ 之 $e$ 評価関数 $P$ に代入し $P$ を最小

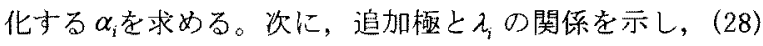
式に $\alpha_{i}, \lambda_{i}$ と追加極を単位円周上に配置寸る条件を代入する ことにより評価関数の荷重行列 $Q, R$ と追加極の関係を誘 導する。

まず，最適有限整定操作量 $\boldsymbol{u}_{k}$ は (27) 式で与えられてお り，この $u_{k}$ を(4) 式の $y=G u_{k}$ に代入し(2)式の $g_{i}=b_{i}-\sum_{j=1}^{i} a_{j} g_{i-j}$ を用いて整理すると, 出力応答 $y=\left[\bar{y}_{1}, \bar{y}_{2}, \cdots, \bar{y}_{N+1}\right]^{T}$ は

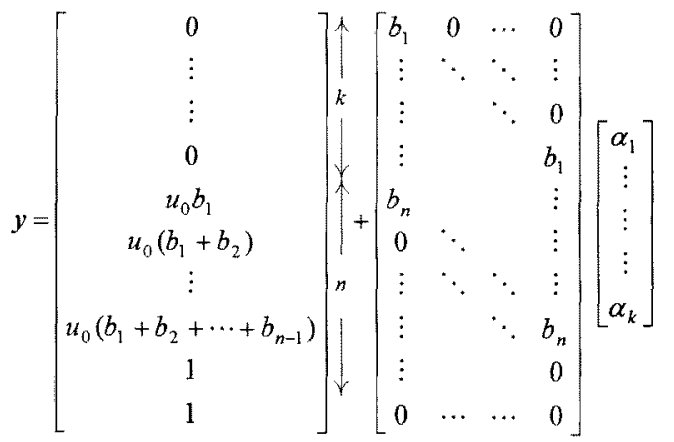

となる。この出力态答 $y$ と目標值 $i_{r}$ との偏差 $e=i_{r}-G u_{k}=$ $\left[e_{1}, e_{2}, \cdots, e_{N+1}\right]^{T}$ 江(7)式と(33)式加方

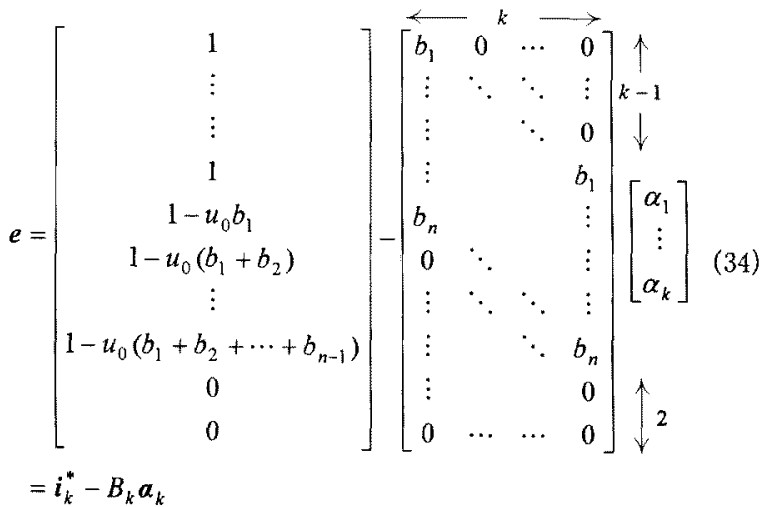


を得る。また，(8)式の評価関数 $P=(1 / 2)\left[e^{T} Q \boldsymbol{e}+\boldsymbol{u}_{k}^{T} R \boldsymbol{u}_{k}\right]$ の 荷重行列 $Q, R を Q=q I_{N}, R=r I_{N}\left(I_{N}\right.$ : 单位行列) とし, (27) 式 の $\boldsymbol{u}_{k}=\boldsymbol{u}_{k}^{*}+A_{k} \boldsymbol{\alpha}_{k}$ と(34) 式の $\boldsymbol{e}=\boldsymbol{i}_{k}^{*}-\boldsymbol{B}_{k} \boldsymbol{\alpha}_{k}$ を代入すれば評価 関数 $P$ 没次式のように表せる。

$$
P=\frac{1}{2}\left[r\left(u_{k}^{*}+A_{k} \alpha_{k}\right)^{T}\left(u_{k}^{*}+A_{k} \alpha_{k}\right)+q\left(i_{k}^{*}-B_{k} \alpha_{k}\right)^{T}\left(i_{k}^{*}-B_{k} \alpha_{k}\right)\right]
$$

したがって，(35)式を $\boldsymbol{\alpha}_{k}$ で偏微分した結果を 0 とおくこと により評価関数 $P$ を最小化する $\boldsymbol{a}_{k}$ は

$$
\left(r A_{k}^{T} A_{k}+q B_{k}^{T} B_{k}\right) \alpha_{k}=\left(q B_{k}^{T} i_{k}^{*}-r A_{k}^{T} u_{k}^{*}\right)
$$

を解くことにより求められる。

説明の簡略化のため前例の $n=2, N=4(k=2)$ の場合を考え れば，最適有限整定操作量 $\boldsymbol{u}_{2}=\left[\bar{u}_{0}, \bar{u}_{1}, \bar{u}_{2}, \bar{u}_{3}, \bar{u}_{4}\right]^{T}$ は (29) 式吕 b $\boldsymbol{u}_{2}=\boldsymbol{u}_{2}^{*}+A_{2} \boldsymbol{\alpha}_{2}$ が得られている。一方, 偏差 $e=\left[e_{1}, e_{2}, \cdots\right.$, $\left.e_{N+1}\right]^{T}$ 江(34)式加的

$$
e=i_{r}-G \boldsymbol{u}_{k}=\left[\begin{array}{c}
1 \\
1 \\
1-u_{0} b_{1} \\
0 \\
0
\end{array}\right]-\left[\begin{array}{cc}
b_{1} & 0 \\
b_{2} & b_{1} \\
0 & b_{2} \\
0 & 0 \\
0 & 0
\end{array}\right]\left[\begin{array}{c}
\alpha_{1} \\
\alpha_{2}
\end{array}\right]
$$

が得られる。よって， $\boldsymbol{u}_{2}^{*}, i_{2}^{*}, A_{2}, B_{2}, \boldsymbol{\alpha}_{2}$ はそれぞれ

$$
\begin{aligned}
& u_{2}^{*}=\left[0,0, u_{0}, u_{1}, u_{2}\right]^{T} \\
& i_{2}^{*}=\left[1,1,1-u_{0} b_{1}, 0,0\right]^{T} \\
& A_{2}=\left[\begin{array}{lllll}
1 & a_{1} & a_{2} & 0 & 0 \\
0 & 1 & a_{1} & a_{2} & 0
\end{array}\right]^{T} \\
& B_{2}=\left[\begin{array}{lllll}
b_{1} & b_{1} & 0 & 0 & 0 \\
0 & b_{1} & b_{1} & 0 & 0
\end{array}\right]^{T} \\
& \boldsymbol{\alpha}_{2}=\left[\alpha_{1}, \alpha_{2}\right]^{T}
\end{aligned}
$$

と表せる。したがって，荷重行列を対角行列にとり， $Q=\operatorname{diag}[q, q], R=\operatorname{diag}[r, r]$ とすれば，評価関数 $P$ は次式とな る。

$$
P=\frac{1}{2}\left[r\left(u_{2}^{+}+A_{2} \boldsymbol{\alpha}_{2}\right)^{T}\left(\boldsymbol{u}_{2}^{*}+A_{2} \boldsymbol{\alpha}_{2}\right)+q\left(i_{2}^{*}-B_{2} \boldsymbol{\alpha}_{2}\right)^{T}\left(i_{2}^{*}-B_{2} \boldsymbol{\alpha}_{2}\right)\right]
$$

上式を $\alpha_{2}$ で偏微分し，P最小化する $\boldsymbol{a}_{2}$ を求めれば (36)，(38) 式から次式が得られる。

$$
a_{2}=\left[\begin{array}{l}
\alpha_{1} \\
\alpha_{2}
\end{array}\right]=\left[\begin{array}{l}
\left\{\left\{r\left(1+a_{1}^{2}+a_{2}^{2}\right)+q\left(b_{1}^{2}+b_{2}^{2}\right)\right\}\left\{q\left(b_{1}+b_{2}\left(1-b_{1}+b_{2}\right)\right)-r a_{2} u_{0}\right\}\right. \\
-\left\{r\left(a_{1}+a_{1} a_{2}\right)+q b_{1} b_{2}\right\}\left\{q\left(b_{1}+b_{2}\left(1-b_{1} u_{0}\right)\right)-r\left(a_{1} u_{0}-a_{2} u_{1}\right)\right] / \Delta \\
\\
{\left[\left\{r\left(1+a_{1}^{2}+a_{2}^{2}\right)+q\left(b_{1}^{2}+b_{2}^{2}\right)\right\}\left\{q\left(b_{1}+b_{2}\left(1-b_{1} u_{0}\right)\right)-r\left(a_{1} u_{0}-a_{2} u_{1}\right)\right\}\right.} \\
-\left\{r\left(a_{1}+a_{1} a_{2}\right)+q b_{1} b_{2}\right\}\left\{q\left(b_{1}+b_{2}\right)-r a_{2} u_{0}\right] / \Delta
\end{array}\right]
$$

ただし，

$$
\Delta=\left[r\left(1+a_{1}^{2}+a_{2}^{2}\right)+q\left(b_{1}^{2}+b_{2}^{2}\right)-\left\{r\left(a_{1}+a_{1} a_{2}\right)+q b_{1} b_{2}\right\}\right]^{2}
$$

である。

ここで, 追加極 $\psi_{i}$ 方評価関数の荷重行列 $Q, R$ の值によっ $\tau z$ 平面上に配置されるが，単位円内，単位円上，単位円 外の3 領域について考える。まず，追加多項式 $\lambda(z)$ のパラ

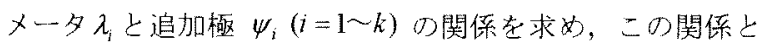
追加極を $z$ 平面の単位问周上に配置与る条件を用いて評価 関数の荷重行列 $Q ， R$ と追加極の関倸を導出古る。追加多 項式 $\lambda(z)$ は，(18)式か $ら \quad \lambda(z)=1+\sum_{i=1}^{k} \lambda_{i} z^{-i}$ であり $z$ にいて $\lambda(z)=z^{k}+\lambda_{i} z^{k-1}+\cdots+\lambda_{k-1} z+\lambda_{k}$ L表せる。，k=1 の場合, $\lambda(z)$ $=z+\lambda_{1}$ となるから $\lambda(z)=0$ の根を $z$ 平面の単位円上に配置

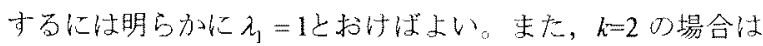
追加極を一般的に複素数上仮定し $\psi_{1}=\eta+j \delta ， \psi_{2}=\eta-j \delta$ とすれば $\lambda(z)$ は

$$
\begin{aligned}
\lambda(z)=z^{2}+\lambda_{1} z+\lambda_{2} & =(z-\eta-j \delta)(z-\eta+j \delta) \\
& =z^{2}-2 \eta z+\eta^{2}+\delta^{2}
\end{aligned}
$$

と表すことができ，(42)式の両辺を比較することにより $=-2 \eta, \lambda_{2}=\eta^{2}+\delta^{2}$ 得古。ここで $\lambda_{2}=\eta^{2}+\delta^{2}=1$ とおけ ば

$$
\left|\psi_{1}\right|=\left|\psi_{2}\right|=\sqrt{\eta^{2}+\delta^{2}}=1
$$

となり $\lambda_{2}=1$ とおくことは追加極を単位円周上に配置したこ ととなる。同様にして，任意のkに刘して $\lambda_{k}=1$ とすれば $k$ 個の追加極の大きさ结 $\left|\psi_{1}\right|=\left|\psi_{2}\right|=\cdots=\left|\psi_{k}\right|=1$ 上なり, 全ての 追加極は単位用上に存在する。なお， $k$ が奇数ならば $\lambda_{k}$ $=-10$ 場合考考方れるが，以下の上らに誘導される条件 式に扔いてqまたは $r$ に負の值が生じる。（8）式において 仮定した正定対称な荷重行列の定義に反することから $\lambda_{k}=$ 一1は考えなくてよい。そこで, 例題の $k=2$ の場合 (28)式か 5

$$
\lambda_{2}=\left(u_{0}-\alpha_{2}\right) / \alpha_{1}
$$

となり，(40)式から得られる $\alpha_{1}, \alpha_{2}$ 代入し $\lambda_{2}=1$ とおいて 整理すれ征，追加極学位円周上に配置した場合のqとr の関倸式が次式の上うに求方。

$$
q\left(\frac{b_{1}+b_{2}}{1+a_{1}+a_{2}}\right)^{2}=q K^{2}=r
$$

ここに，Kは制御対象のダインである。(45)式泣 $z$ 平面の 単位円周上に追加極老配置する条件式であり $n=2, k=2$ D 場合について導出したが, この関倸式 $q K^{2}=r$ は $N=n+k$ $(k \geqq 1)$ とした一般的な場合にも成立寸る。したがって，一 般的な $q$ 上 $r$ 関係学单位円基準しした追加極の位置に ついて分けて表せば次式の上うになる。

$\begin{array}{ll}q K^{2}>r & \text { (単位円内) } \\ q K^{2}=r & \text { (単位円周上) } \\ q K^{2}<r & \text { (临位田外) }\end{array}$


無定位性の場合は，Kが鲢限大と考えられることから全て の追加極泣䍩位丹周内に存在し

$$
q K^{2}>r \quad \text { (単位円内) }
$$

が常に成り立ち, 荷重行列 $q$ を固定した場合荷重 $r$ を大き

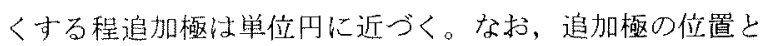
有限整定応答の関係を検討するため，5章で最適有限整定 サーボ采の設計を行い，6章で荷重行列を変化させた数值 例老示寸。

\section{5. 最適有限整定サーボ系の設計}

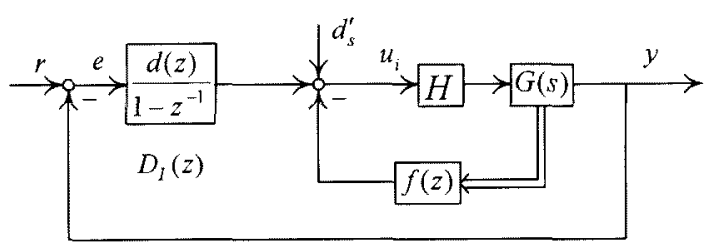

図 1 最適有限整定サーボ系の構成

Fig. 1. Configuration of optimal deadbeat servosystem.

本章では，2章で求めたオ一バパラメータモデルのパラ メー夕 $\bar{a}(z), \bar{b}(z)$ を用いて，(20)式の規範モデル応答 $\bar{y}(z)$ $=\bar{u}_{0} \bar{b}(z) /\left(1-z^{-1}\right)$ と䦥ループ店答が一致する1形サーボ系孝 設計する。最適有限整定サーボ系の制御構成梳，文献 1) で提案されている図10制御構成を用いることとする。主 ループに積分要素をもった緩和フィルタ $D_{I}(z)$ を加え, 状態 フィードバックによって局部補償される閉ループ采を考え

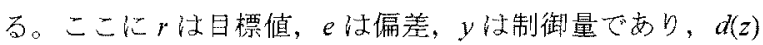
および $f(z)$ は次式で与えられるものとする。

$$
\begin{array}{ll}
d(z)=\sum_{i=0}^{l} d_{i} z^{-i} & (l=N-n) \\
f(z)=\sum_{i=1}^{m} f_{i} z^{-i} & (m=\max (n, n+l-1))
\end{array}
$$

なお，フィードバックゲイン $f(z)$ の次数 $m$ 牥最適制卸段 数 $N$ 上り定まり，過去の状態值もフィードバックしてい る。一方, 図 1 の閨ループ采の伝達関数 $G_{\bar{y}}(z)$ は次式の上 らに表される。

$G_{\bar{y}}(z)=\frac{b(z) d(z)}{\left(1-z^{-1}\right)\{1+a(z)+f(z)\}+b(z) d(z)}=\frac{b(z) d(z)}{R(z)}$

ここで，閍ループ系が $N=n+k$ 段で有限整定するためには， $G_{\bar{y}}(z)$ のすぶての極を零に配置することから $G_{\bar{y}}(z)$ の分母で 方名R(z)=1 が成立すればよい。このとき，閉ループ系の単 位ステップ入力に対する応答は (50) 式から

$$
\bar{y}(z)=b(z) d(z) /\left(1-z^{-1}\right)
$$

上表され，(20) 式の有限整定念答 $\bar{y}(z)=\bar{u}_{0} \bar{b}(z) /\left(1-z^{-1}\right)$ 上一 致寸ればよいので，両式を比較すれば $d(z)=\bar{u}_{0} \lambda(z)$ 方得ら れる。ここで, $\lambda(z)$ の゚ラメータ $\lambda_{i}$ は, (19) 式で与えられ るから, $d(z)$ のパラメータ $d(i=0 \sim k)$ は

$$
d_{i}=\bar{u}_{0} \lambda_{i}=\bar{u}_{0}\left(\bar{a}_{i}-\sum_{j=1}^{n} \lambda_{i-j} a_{j}\right)
$$

と定まる。また，(50)式の $R(z)=1$ とおき，(52)式のd 老代 入して $z^{-1}$ のべき乗の係数をすべて零とおけぱ，フィード バックゲイン $f(z)$ のパラメータ $f(i=1 \sim m)$ は次式のように 得られる。

$$
f_{i}=-a_{i}+\bar{u}_{0} \sum_{j=i+1}^{m} \bar{b}_{j}
$$

な抢，N=nと㧍けげ(48)，(49)式のl=0 で $d(z)=u_{0}$ とおく ことになり，図1の制御系は最短時間有限整定制御系とな z。

以上の上うに設計された $d(z), f(z)$ を用いて図 1 の制御系 を構成寸れば，最適有限整定 1 形サーボ系が状態つィード バックによって実現できる。

また， $d(z), f(z)$ はステップ状目標值に注目して最適有限 整定制御系設計したが，ステップ状の外乱に対しても有 限整定応答功得られる制御系となっている。図 1 に括いて 制御対象の入力端に加わる外乱を $d_{s}^{\prime}$, 出力㐫答を $y^{\prime}$ 七れ ば, $d_{s}^{\prime}$ と $y^{\prime}$ の間の閉ループ伝達関数は

$$
G^{\prime}(z)=\frac{y^{\prime}(z)}{d_{s}^{\prime}(z)}=\frac{b(z)}{\left(1-z^{-1}\right)\{1+a(z)+f(z)\}+b(z) d(z)}
$$

となる。よって，ステップ状の外乱 $d_{s}^{\prime}$ に対する応答性整定 条件 $R(z)=1$ を代入すれば $y^{\prime}(z)=b(z)$ となり, $b(z)$ の次数は nであるから，図1のサ一ボ系は入力端に加わるステップ状 外乱に詨し，n段で有限整定する。

\section{6. 数值例}

2つの例題について前章で説明したサーボ系の設計例を 示し，パラメータ変動が扔こった場合に(46)，(47)式の条件 が出力応答にどのように影響するかをディジタルシミュ レーションによって検討する。

まず，伀達関数が $G(s)=1 /\left(1+0.4 s+s^{2}\right)$ で表される定位性の 制御対象を考え，サンプル周期を $\theta=1.0 \mathrm{sec} と し ，(8)$ 式の 科価関数の荷重行列を $Q=I$ ( $I$ : 筆位行列) に固定し, $R=0.01 I, I, 100 I$ の場合についてサーボ系設計する。

$G(s)$ の最短制御段数は $N=n=2$ であり，刘忘与る最短有限 整定操作量は (11) 式加得られ

$$
\boldsymbol{u}_{0}=[1.319,0.115,1.000]^{T}
$$

となる。この操作量に対する $G(s)$ の岕答 $y_{i}$ は(4)式から得 られるので，(12)式から $a_{i}, b_{i}$ を求めれば対応するパルス 伝達関数 $G(z)$ 屿次式の上うに求まる。 


\section{表 1 数値例}

Table 1. Numerical examples.

\begin{tabular}{|c|c|c|c|c|c|c|c|c|}
\hline \multicolumn{5}{|c|}{ (A) } & \multicolumn{3}{|c|}{$G(s)=\frac{1}{1+0.4 s+s^{2}}$} & \multirow{2}{*}{$\begin{aligned} \theta=1.0 \mathrm{sec}, Q=I \\
f(z), \lambda(z), \psi\end{aligned}$} \\
\hline$N$ & $R$ & i & 0 & 1 & 2 & 3 & 4 & \\
\hline \multirow{3}{*}{2} & & \begin{tabular}{|l|}
$u_{i}$ \\
\end{tabular} & 1.319 & 0.115 & 1.000 & & & \multirow{3}{*}{$\begin{array}{l}f(z)=1.377 z^{-1}-0.670 z^{-2} \\
\lambda(z)=1\end{array}$} \\
\hline & & $a_{i}$ & & -0.912 & 0.670 & & & \\
\hline & & $b_{i}$ & & 0.405 & 0.352 & & & \\
\hline \multirow{9}{*}{4} & \multirow{3}{*}{$0.01 I$} & $\bar{u}_{i}$ & 1.972 & -0.744 & 1.678 & 0.823 & 1.000 & \multirow{3}{*}{$\begin{array}{l}f(z)=1.113 z^{-1}-0.794 z^{-2}+0.093 z^{-3} \\
\lambda(z)=1-0.464 z^{-1}+0.133 z^{-2} \\
\psi=0.232 \pm 0.282 i\end{array}$} \\
\hline & & $\overline{\bar{a}}_{i}$ & & -1.377 & 1.228 & -0.433 & 0.089 & \\
\hline & & $\bar{b}_{i}$ & & 0.405 & 0.164 & -0.109 & 0.047 & \\
\hline & \multirow{3}{*}{$I$} & $\bar{u}_{i}$ & 0.429 & 0.498 & 0.794 & 0.712 & 1.000 & \multirow{3}{*}{$\begin{array}{l}f^{\prime}(z)=1.738 z^{-1}-0.182 z^{-2}+0.151 z^{-3} \\
\lambda^{\prime}(z)=1+1.074 z^{-1}+z^{-2} \\
\psi^{\prime}=-0.537 \pm 0.843 i\end{array}$} \\
\hline & & $\bar{a}_{i}$ & & 0.162 & 0.689 & -0.192 & 0.670 & \\
\hline & & $\bar{b}_{i}$ & & 0.405 & 0.788 & 0.784 & 0.352 & \\
\hline & \multirow{3}{*}{$100 I$} & $\bar{u}_{i}$ & -0.096 & 0.519 & 0.861 & 0.404 & 1.000 & \multirow{3}{*}{$\begin{array}{l}f^{\prime \prime}(z)=1.951 z^{-1}+0.189 z^{-2}+0.313 z^{-3} \\
\lambda^{\prime \prime}(z)=1-5.472 z^{-1}-9.211 z^{-2} \\
\psi^{\circ}=6.822,-1.350\end{array}$} \\
\hline & & $\bar{a}_{i}$ & & -6.384 & -3.548 & 4.736 & -6.174 & \\
\hline & & $\bar{b}_{i}$ & & 0.405 & -1.863 & -5.662 & -3.250 & \\
\hline \multicolumn{3}{|c|}{ (B) } & \multicolumn{5}{|c|}{$G(s)=\frac{1}{s\left(1+0.4 s+s^{2}\right)}$} & $\theta=1.5 \sec , Q=I$ \\
\hline \begin{tabular}{|l|}
$N$ \\
\end{tabular} & $R$ & i & 0 & 1 & 2 & 3 & 4 & $f(z), \lambda(z), \psi$ \\
\hline \multirow{3}{*}{2} & & $u_{i}$ & 0.476 & -0.071 & 0.261 & 0.000 & & \multirow{3}{*}{$\begin{array}{l}f(z)=2.722 z^{-1}-1.427 z^{-2}+0.670 z^{-2} \\
\lambda(z)=1\end{array}$} \\
\hline & & $a_{i}$ & & -1.149 & 0.698 & -0.548 & & \\
\hline & & $b_{i}$ & & 0.437 & 1.340 & 0.320 & & \\
\hline \multirow{3}{*}{\multicolumn{2}{|c|}{0.011}} & $\bar{u}_{i}$ & 0.732 & -0.365 & 0.440 & -0.140 & 0.000 & \multirow{3}{*}{$\begin{array}{l}f(z)=1.828 z^{-1}-0.889 z^{-2}+0.466 z^{-3} \\
\lambda(z)=1-0.349 z^{-1} \\
\psi=0.349\end{array}$} \\
\hline & & $\bar{a}_{i}$ & & -1.499 & 1.100 & -0.793 & 0.191 & \\
\hline & & $\bar{b}_{i}$ & & 0.437 & 1.187 & -0.148 & -0.112 & \\
\hline \multirow{6}{*}{4} & \multirow{3}{*}{$I$} & $\bar{u}_{i}$ & 0.439 & -0.029 & 0.236 & 0.020 & 0.000 & \multirow{3}{*}{$\begin{array}{l}f^{\prime}(z)=1.956 z^{-1}-0.496 z^{-2}+0.560 z^{-3} \\
\lambda^{\prime}(z)=1+0.082 z^{-1} \\
\psi^{\prime}=-0.082\end{array}$} \\
\hline & & $\bar{a}_{i}$ & & -1.066 & 0.603 & -0.490 & -0.045 & \\
\hline & & $\bar{b}_{i}$ & & 0.437 & 1.376 & 0.431 & 0.026 & \\
\hline & \multirow{3}{*}{$100 I$} & 倍 & 0.241 & 0.198 & 0.097 & 0.128 & 0.000 & \multirow{3}{*}{$\begin{array}{l}f^{\prime \prime}(z)=2.043 z^{-1}-0.230 z^{-2}+0.624 z^{-3} \\
\lambda^{\prime \prime}(z)=1+0.972 z^{-1} \\
\psi^{\prime \prime}=-0.972\end{array}$} \\
\hline & & $\bar{a}_{i}$ & & -0.177 & -0.419 & 0.130 & -0.533 & \\
\hline & & $\bar{b}_{i}$ & & 0.437 & 1.765 & 1.623 & 0.311 & \\
\hline
\end{tabular}

$$
G(z)=\frac{0.405 z^{-1}+0.352 z^{-2}}{1-0.912 z^{-1}+0.670 z^{-2}}
$$

また，制御段数を $N=4(k=2)$ とすれば，最適有限整定操作 量 $\boldsymbol{u}_{2}$ は(13) 式から

$$
\left.\begin{array}{ll}
\boldsymbol{u}_{2}=[1.972,-0.744,1.678,0.823,1.000]^{T} & (Q=I, R=0.01 I) \\
\boldsymbol{u}_{2}^{\prime}=[0.429,0.498,0.794,0.712,1.000]^{T} & (Q=I, R=I) \\
\boldsymbol{u}_{2}^{\prime \prime}=[-0.096,0.519,0.861,0.404,1.000]^{T} & (Q=I, R=100 I)
\end{array}\right\}
$$

が得られる。ここで(57)式の操作量に対応寸る応答牙は(4) 式加ら得られるので $\bar{a}_{i}, \bar{b}_{i}$ を(16)式から求めれば，刘応古る オーバパラメータモデル $\bar{G}(z)$ は次式のように求まる。

$$
\begin{aligned}
& \bar{G}(z)=\frac{0.405 z^{-1}+0.164 z^{-2}-0.109 z^{-3}+0.047 z^{-4}}{1-1.377 z^{-1}+1.228 z^{-2}-0.433 z^{-3}+0.089 z^{-4}} \\
& \bar{G}^{\prime}(z)=\frac{0.405 z^{-1}+0.788 z^{-2}+0.784 z^{-3}+0.352 z^{-4}}{1+0.162 z^{-1}+0.689 z^{-2}-0.192 z^{-3}+0.670 z^{-4}} \\
& \bar{G}^{\prime \prime}(z)=\frac{0.405 z^{-1}-1.863 z^{-2}-5.662 z^{-3}-3.250 z^{-4}}{1-6.384 z^{-1}-3.548 z^{-2}+4.736 z^{-3}-6.174 z^{-4}}
\end{aligned}
$$

さらに，(56)，(58)式のパラメータ $a_{i}, \bar{a}_{i}$ と(19)式から

$$
\begin{aligned}
& \lambda(z)=1-0.464 z^{-1}+0.133 z^{-2} \\
& \lambda^{\prime}(z)=1+1.074 z^{-1}+z^{-2} \\
& \lambda^{\prime \prime}(z)=1-5.472 z^{-1}-9.211 z^{-2}
\end{aligned}
$$

を得る。この $\lambda(z)$ 上 (57) 式の最適有限整定操作量の初段の 值 $\bar{u}_{0}$ を用いれば，(52)式より主ループ緩和フィルタ $D_{l}(z)$ の 分子 $d(z)$ は次式となる。

$$
\begin{aligned}
& d(z)=1.972-0.917 z^{-1}+0.263 z^{-2} \\
& d^{\prime}(z)=0.429+0.461 z^{-1}+0.429 z^{-2} \\
& d^{\prime \prime}(z)=-0.096+0.527 z^{-1}+0.888 z^{-2}
\end{aligned}
$$

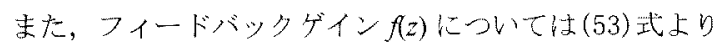

$$
\begin{aligned}
& f(z)=1.113 z^{-1}-0.794 z^{-2}+0.093 z^{-3} \\
& f^{\prime}(z)=1.738 z^{-1}-0.182 z^{-2}+0.151 z^{-3} \\
& f^{\prime \prime}(z)=1.951 z^{-1}+0.189 z^{-2}+0.313 z^{-3}
\end{aligned}
$$



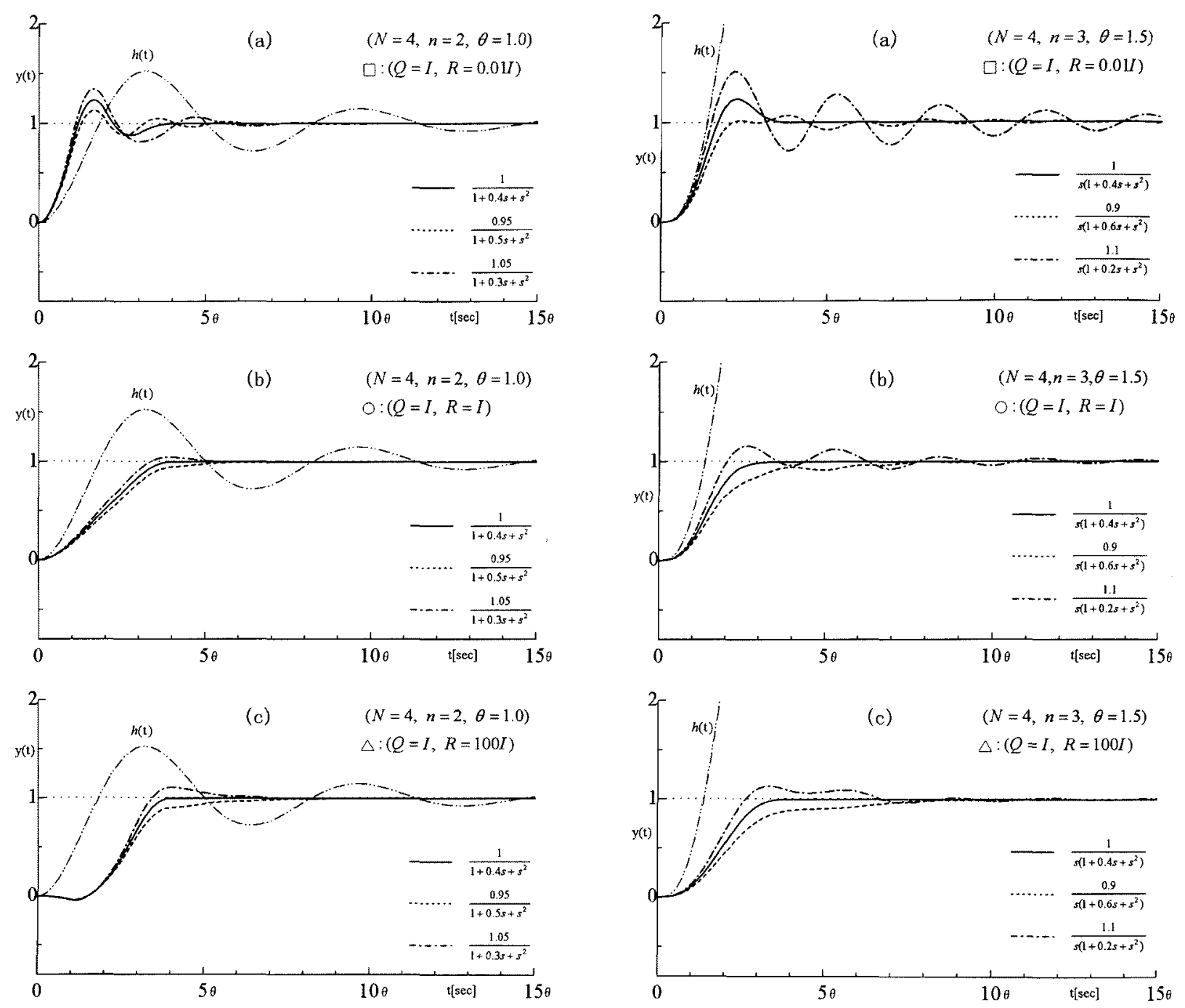

図 2 最適有限整定制御の比較 $G(s)=1 /\left(1+0.4 s+s^{2}\right)$

Fig. 2. Comparison of the optinal deadbeat responses.

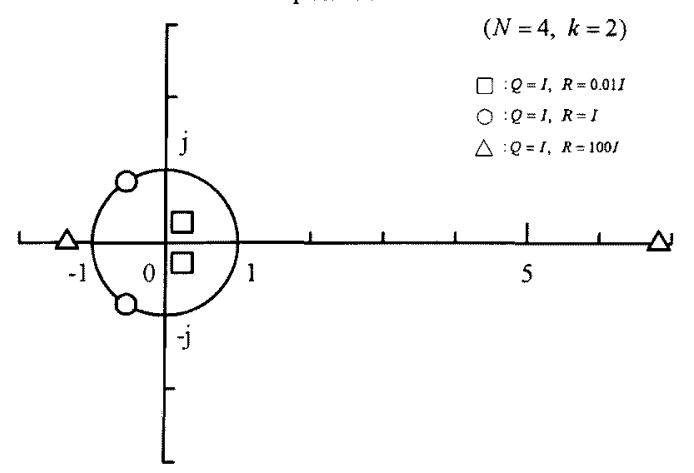

図 4 最適有限整定制卸の比較 $G(s)=1 /\left\{s\left(1+0.4 s+s^{2}\right)\right\}$

Fig. 4. Comparison of the optinal deadbeat responses.

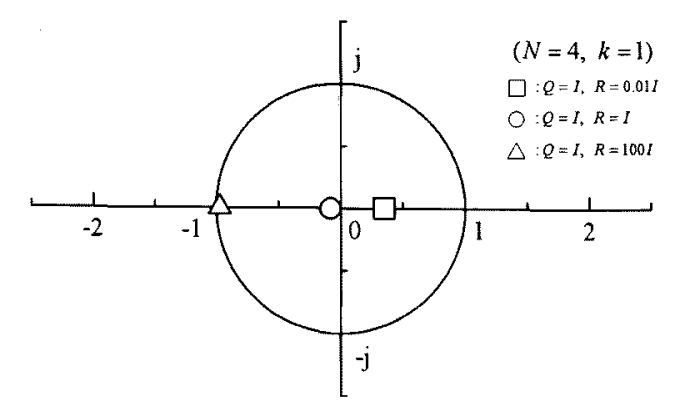

図 3 追加極の位置 $G(s)=1 /\left(1+0.4 s+s^{2}\right)$

Fig. 3. Position of extra pole.

図 5 追加極の位置 $G(s)=1 /\left\{s\left(1+0.4 s+s^{2}\right)\right\}$

Fig. 5. Position of extra pole. 
以上のように設計された最適有限整定操作量, 制御装置 およびれ(z)を表 1 (A)に整理して示した。

次に, 制御対象の伝達関数が $G(s)=1 /\left\{s\left(1+0.4 s+s^{2}\right)\right\}$ で表 される無定位性の系を考え, サンプル周期を $\theta=1.5 \mathrm{sec}$, 評 価関数の荷重行列を $Q=I$ に固定し $R=0.01 I, I, \mathrm{I} 00 I$ とし， 制御段数を $N=4$ と選んだ場合についても同様に設計を行い 表 1 (B)に整理して示した。

ここで, $G(s)=1 /\left(1+0.4 s+s^{2}\right)$ に対し表 $1(\mathrm{~A})$ のように設計 された制御装置を用いて, 図 1 のサーボ系を構成した場合 におけるステップ状目標值に対する出力応答のディジタル シミュレーション結果を図 2 の (a), (b)，(c)に示した。な お, 制御対象はゲイン $K=1$, 減衰定数 $\zeta=0.2$ なる 2 次振動 系であるが，ゲイン $K に \pm 5 \%$, 減衰定数らに士2 $5 \%$ の パラメータ変動を与えた場合の灾答を”点線”と”一点鎖 線”で示している。また, 同図における (a) は $(Q=I, R=0.01$ $I), \quad(\mathrm{b})$ は $(Q=I, R=I), \quad(\mathrm{c})$ は $(Q=I, R=100 I)$ の場合であり, こ のときの追加極の移動の様子を図 3 に示している。ここで (a)，(b)，(c)を比較すれば，荷重行列を $(Q=I, R=I)$ 上選び追 加極を単位円周上に配置した (b) 図がパラメータ変動に対し 過渡応答波形の誤差が比較的小さく整定時間が他の态答と 比へ短くなっている。

次に, $G(s)=1 /\left\{s\left(1+0.4 s+s^{2}\right)\right\}$ に対し表 1 (B)のように設計 された制御装置を用いて, 図 1 のサーボ系を構成した場合 のステップ状目標值に対する出力応答のディジタルシミュ レーション結果と伝達関数にパラメータ変動を与えた場合 の応答を図 4 に示した。また，このときの追加極を図 5 に 示した。ここで, 図 $4(\mathrm{a}),(\mathrm{b}),(\mathrm{c})$ を比較すると, 荷重行列 $(Q=I, R=100 I)$ と選び追加極をもっとも単位円周近傍に配置 した (c) 図がパラメータ変動に対して図 2 (b) と同様な結果 となっている。

制御仕様における速応性の面からも検討を要するため, 制御段数 $N$ と評価関数の荷重行列 $Q, R$ をいかに選ぶかは 課題の一つであるが, 上記の結果から単位円の近傍に追加 極を配置すればパラメータ変動に対してより良好な応答が 得られ，(46)式の $q K^{2}=r$ なる条件は一つの目安となるこ とがわかる。

\section{7. まとめ}

制御対象のステップ応答を用いた簡単な行列演算から, 偏差 $\boldsymbol{e}$ と操作量 $\boldsymbol{u}_{k}$ に関する 2 次形式評価を最小化する最適 有限整定操作量 $\boldsymbol{u}_{k}$ を求め, この $\boldsymbol{u}_{k}$ に対する制御対象の出 力応答を閉ループ系の規範モデル応答とする最適有限整定 サーボ系の設計法を示し, 従来の手法よりも実用的なこと をこれまで指摘してきた。しかし，e, $u_{k}$ に対する荷重行列 $Q, R$ をいかにに選ぶかは試行を繰り返す必要があった。そ こで, 筆者らの手法により $\boldsymbol{u}_{k}$ を求め, $\boldsymbol{u}_{k}$ に対応したオーバ パラメータモデル $\bar{G}(z)$ の分母子に含まれる追加多項式 $\lambda(z)$ $=0$ の根 $\psi_{i}$ (追加極) と $Q=q I, R=r I$ ( $I$ : 単位行列) の関係 について $q K^{2}=r$ なる条件を満足すれば，追加極 $\psi_{i}$ を $z$ 平 面の単位円上に配置できることを明らかにした。この条件
を満たすように $q, r$ を選んで，追加極を単位円の近傍に配 置した規範モデルを作れば，良好な制御応答が得られ制御 対象のパラメータ変動に対しても比較的頑健なサーボ采が 設計できた。なお，単位円の近傍への追加極の配置とパラ メータ変動に関する証明は今後の課題である。また，有限 整定サーボ系の設計にお打整定段数 $N$ と $Q, R$ の選択は 制御系設計における大きな課題であるが，ここで得られた 結果は一つの指標を与えるものと思われる。なお, 最適有 限整定サーボ采については文献 1) の制御構成を用いた が，他の制御構成に対しても同様に設計できる。 (平成 10 年 2 月 26 日受付, 平成 10 年 10 月 21 日再受付)

\section{文 献}

（1）西村・米沢：「緩和フィルタを用いる有限時間整定制 御系の設計」，システム制御情報学会論文誌Vol. 4-10, 399/406, 1991

（2）西村・米沢・櫛田：「操作量飽和のある系に対する有 限時間整定制御装置の設計」, 計測自動制御学会論文 集Vol. 22-11, 1134/1141, 1986

（3）瓜倉・長田：「過渡応答を考慮した離散時間システム に対するデッドビート制御」，計測自動制御学会論文 集Vol. 23-4, 353/357, 1987

（4）瓜倉：「連続時間過渡応答を考慮に入れたデッドビー ト制御」，システム制御情報学会論文集Vol.5-6,229/ 234,1992

（5）村田・相良：「インパルス応答を用いた最適有限整定 忘答制御装置の設計」, 計測自動制御学会論女集 Vol. 20-12, 1073/1080, 1984

（6）村田・相良：「状態フィードバックによる最適有限整 定制御系の設計」，電気学会論文誌 C, 109-6, 432/438, 1989

（7）村田・中野・松本：「最適有限整定応答制御系の一設 計法」, 電気学会論文誌 C $116-10,1141 / 1148,1989$

松島 優一 （学生員）1974年8月20日生。1997年3月広

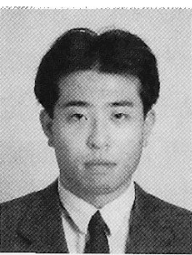
島工業大学電子工学科卒業。同年広島工業 大学大学院工学研究科博士前期課程電子工 学専攻入学, 現在に至る。主として最適有 限整定制御に関する研究に従事。

若宮 真一郎（学生員）1974年12月16日生。1997年3月

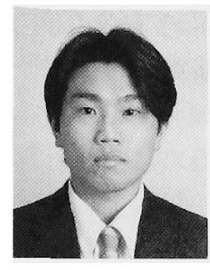
広島工業大学電子工学科卒業。同年広島工 業大学大学院工学研究科博士前期課程電子 工学専攻入学, 現在に至る。主として最適 有限整定制御に関寸る研究に従事。

村田 弘志（正員）電気学会論文誌 Vol.119-C, No.2 1999 参照 